Publisher homepage: www.universepg.com, ISSN: 2707-4641 (Online) \& 2707-4633 (Print)

https://doi.org/10.34104/ijma.020.031037

International Journal of Management and Accounting

Journal homepage: www.universepg.com/journal/ijma

\title{
Green Reporting as a Tool of Environmental Sustainability: Some Observations in the Context of Bangladesh
}

\author{
Md. Mominur Rahman ${ }^{1}$ and Muhammad Shajib Rahman ${ }^{2}$ \\ ${ }^{1 \& 2}$ Department of Accounting and Information Systems, Comilla University, Comilla, Bangladesh. \\ *Correspondence: mominurcou@gmail.com (Md. Mominur Rahman, Research Scholar, Department of AIS, Comilla \\ University, Bangladesh)
}

\begin{abstract}
Green reporting is an innovative outlet of accounting. It deals with accounting for the environment and its wellbeing. An organization can lessen most of the environmental costs by taking effective decisions with the help of green reporting. Core objective of this study is to comprehend the meaning of green reporting and how it can be a tool of environmental sustainability. We discovered the significance of green reporting implication and retain a way of what the companies are taking from the environment and what they are giving back in return. This paper highlights to recognize contemporary tendencies in green reporting. This study would be a policy dialog in the efficient usage of resources and in the reduction of pollution to an extent. Green reporting plays a vital role in the corporate social responsibility of a firm. This study also heightens on the people's insight concerning green reporting with the help of collecting primary data with appropriate execution. It was originated that a maximum of the respondents felt there is a demand for affecting the road to green reporting and that all the companies should jump adopting green reporting.
\end{abstract}

Keywords: Environmental sustainability, Green reporting, Sustainability, Green accounting, and Green report.

\section{INTRODUCTION:}

Green reporting is taken into account to be a momentous tool for understanding the significant facets of eco-friendly environment regarding the economy. Green reporting is the form of accounting which attempts to combine the environmental costs together with the financial cost which would lead to the ultimate outcomes of the operations of the company (Contributors, 2020). The benefit of green reporting initiative is recognized as the aptitude to regulate and create responsiveness regarding costs linked to environment, which in turn aids in detecting the techniques for diminishing and avoiding costs of such type. For this advantageous feature, the presentation of the environment has also been enhanced. Green reporting is not completed obligatory by the central or the state government and also there is no straight forward policy concerning the environmental protection. Alternatively, when the company is acquiring to some degree from the environment, it must also make allowances for the expenses of the environment.

Green reporting focuses to prevent the exhaustion of scarce natural resources and to avoid the environmental degradation. Application of green reporting in the management structure of the organization is imperative for the advancement of ecofriendly and economic achievement of the organization. Green reporting is a route to a sustainable forthcoming when the companies are preparing their financial performance statement and their statement of financial position, they habitually 
consider the internal expenses for example the labor cost and material cost which straightly influence the statement of financial position of the organization (Commission, 2011). External expenses such as the environmental expense, social expense, and the economic expense are often ignored. The company has to be certain to take outside aspects also into consideration so that the scarce resources can be cautiously and efficiently used. It can be taken as an instrument by the company to have a track of all the actions through which the company is acquiring from the environment, keep an account of what it has been doing to give somewhat return to the environment in coming back of what it has achieved and also assess the data as to what procedures have to be occupied to protect the environment which is sooner or later getting washed-out (Agarwal and Kalpaja, 2018).

The environmental expenses that arise due to the financial results of operation of the firm can be measured by means of a green reporting instrument. Green reporting is by means of management instruments to drive in numerous purposes such as enlightening environment achievement, regulatory expenses, financing in cleaner technologies, emerging greener procedures, and carrying out related to product mix, product pricing and product retention (Boje, 1999).

Green reporting drives with diverse purposes as well as perceptions which rarely includes preservative environmental assets as well as it accounts for the alteration in well-being because of the consequence on the environment (Serafy, 1997). It acts an identical significant part in the corporate social responsibility of a company and also runs a dynamic role in decision making of the company regarding the procedures and techniques used and also the cost effectiveness of the company that leads profitability.

Green reporting is available as a tool for environmental communication from the viewpoint of societal accountability. Relevance, reliability, clarity, comparability and verifiability are five essential principles in order to create green reporting as an effective tool for environmental communication and fulfilling social accountability. Environmental repor- ting which does not meet with these principles is more as an environmental pamphlet (Government, 2004).

Therefore, this study signifies that the companies can be the front-runner of green change by incorporating green reporting into their individual company and also encourage other firms to also implement them to have a robust environmental sustainability. With a view to incorporating green accounting at every single level of the organization, advanced environmental accountability can be achieved.

\section{Literature Review:}

Green reporting, also known as green accounting, is to identify, record and reveal the impacts of corporate environmental actions on its financial position through a set of accounting arrangements. Green reporting is a quantitative valuation of the cost and effectiveness of organizations in environmental protection actions. Companies are mandatory to have methodical records and reports and are directed to sustain a positive relationship with natural environment to implement efficient and effective environmental events. The ultimate goal is to attain sustainable development through environmental sustainability (Government, 2005). Green reporting aids the companies to become more conscious of their corporate responsibility along with the government could use the environmental report to have path of the acts of the companies in the direction of the environment. By perceiving the notions based on the green reporting (Abdel-Rahim et $a l ., 2010)$ explored techniques which can be used in environmental reporting. The authors also detected that there is a corresponding rise in measuring the environmental performance as the need for green reporting increases.

Green reporting is becoming more and more common in corporation. As stated by the Institute for Environmental Management and the firm KPMG, $35 \%$ of the world's 250 largest corporations now issue green reports. That denotes an extraordinary change from just a decade before, when it was tough to discover any company's delivering comprehensive data on their environmental presentation to the public. Now, Companies are willingly implementing "green reporting" because it makes decent business 
intelligence (Gazi, 2020). Not only does public reporting attempt companies to be well organized about their green performance, which in turn cuts their environmental risk, it also creates positive image. Decent green reporting can serve as a differentiator in the war for talent people like at work for socially accountable companies and it can create a company more gorgeous to customers and share holders as well. Furthermore, because green reporting places all business operations under scrutiny, it often helps managers to detect cost savings and even new business opportunities (Kolk, 2000).

Otte, (2008) mentioned that there are definite internal together with external benefits to the company if they implemented green reporting. The green house gas emission accounting contains having a path of the emissions, accounting and later reporting them. By applying the green house gas process, there would be advancement in the communication system between the firms and the suppliers which would, in turn, lead to the decreases in the costs. Also, green reporting does have draw backs and barricades as well. But the author remarks confident roots through which the company can overcome these blockades.

Hecht, (1997) defined green reporting as a significant instrument for understanding the character played by the natural environment in the economy. Green accounts provide data which highpoint both the involvement of natural resources to economic wellbeing and the expense levied by pollution or resource degradation. Lehman, (2011) elucidates about interpretive accounting research (IAR). The key objective of IAR is to comprehend how the accounting department like management accounting might assist in overcoming or defeating issues regarding sustainability considerations and global warming. The author also illustrates how interpretive accounting study allows people to reconsider the construction and approaches towards the natural world. Chauhan, (2005) described the possibility limitations and authorized framework of green reporting. He highlighted on the environmental policy, agreement with the rules and regulation and solid steps for pollution control.
Very few firms have satisfactory information about environmental matters and those who have primarily concentrated on category of trick connected for pollution regulator, phases for energy consumption, phases for waste-water generation, etc. Therefore, suitable information with regard to resource usage is not categorically available but such information is crucial for practicing sustainable development (Malik and Mittal, 2015).

The study on 'Relationship between environmental accounting and pillars of sustainability' described the complexities and challenges regarding sustainable development. The purpose of that study was to figure out and come to a decision whether the social and integration point of view is external of the green reporting concept. At the end of the study, after various literature reviews and researches, the author was able to reach to a decision that green reporting cannot be beyond social and integration contest of sustainability and so, it can be connected to the supports of sustainability (Harazin and Horvath, 2011).

Objectives of the study: The study aims at the following objectives-

1. To understand the meaning of green reporting.

2. To create awareness about the implementation of green reporting. Also known as green accounting.

3. To make company realize the need and significance of green reporting.

4. To make an effort to have the green reporting as a part of the company's accounts.

\section{METHODOLOGY:}

In this study, the primary data was collected and an exploratory study with a survey method was directed to comprehend people's observation on the road to green reporting and its implication. This study was conducted in Bangladesh throughout the period of January, 2020 and the sample of 120 respondents was designated for the study. The research study targeted the working professionals and students. The primary data was composed and managed using a wellorganized questionnaire. 
Likert's scale of agreement (Strongly agree, Agree, Neutral, Disagree and strongly disagree) was used. The score of 5 was used to represent "Strongly agree" while the score of 1 represented "strongly disagree" on the scale. The collected data was arranged and tabulated for examination in accordance with the objectives of the study.

We prepared the questionnaire with three questions. They are; question no. 1, "Should green reporting be implicated in all companies?", question no. 2, "Should Much more awareness be created about green reporting?", question no. 3, "Must strong actions have to be taken by the government if green reporting is not followed?"

\section{RESULT AND DISCUSSION:}

Analysis and Explanation: A questionnaire was prepared with a view to collecting the primary data and explanation was done with the help of final results after analyzing the data. The analysis was done with the following steps:

Step 1: The percentage analysis was used to study the general outline of the respondents.

Step 2: The analysis of attitude of the respondents by percentage with the help of Google forms.

Table 1 showed the percentage analysis of the general outline of the respondents. The general outline of the respondents is categorized into three forms i.e. occupation, age group and gender.

The primary data was collected from of 120 respondents. The above Table 1 shows that Out of the 120 respondents, 66(55\%) respondents were employees, then $42(35 \%)$ of them were students, and the rest $12(10 \%)$ were businessmen. Male and Female respondents were $60(50 \%)$, and 60(50\%) respectively.

Age group of 20-30 years included 62(51.67\%) respondents, 30(25\%) was in the age group of 30-40 years, $14(11.67 \%)$ respondents were under $40-50$ age group, $8(6.66 \%)$ were in the age group of 50-60 years and $6(5 \%)$ taken to another age group excluding the above-revealed age group Fig 1.
Table 1: Analysis of general profile of the respondents.

\begin{tabular}{|c|c|c|c|}
\hline & Classification & $\begin{array}{c}\text { No. of } \\
\text { Respondents }\end{array}$ & $\begin{array}{c}\text { Percentage } \\
(\%)\end{array}$ \\
\hline \multirow{4}{*}{ 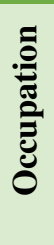 } & Employees & 66 & $55 \%$ \\
\hline & Students & 42 & $35 \%$ \\
\hline & Businessman & 12 & $10 \%$ \\
\hline & Total & 120 & $100 \%$ \\
\hline \multirow{6}{*}{ 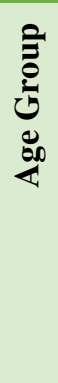 } & 20-30 years & 62 & $51.67 \%$ \\
\hline & $30-40$ years & 30 & $25 \%$ \\
\hline & $40-50$ years & 14 & $11.67 \%$ \\
\hline & $50-60$ years & 8 & $6.66 \%$ \\
\hline & Others & 6 & $5 \%$ \\
\hline & Total & 120 & $100 \%$ \\
\hline \multirow{3}{*}{ 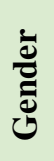 } & Male & 60 & $50 \%$ \\
\hline & Female & 60 & $50 \%$ \\
\hline & Total & 120 & $100 \%$ \\
\hline
\end{tabular}

Source: Primary Data

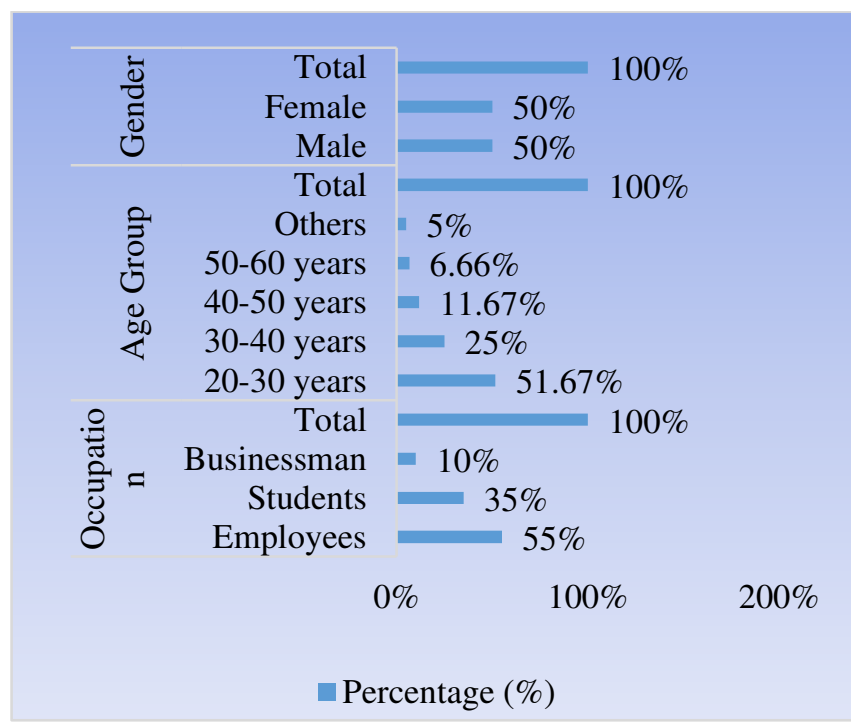

Fig 1: Comparable general profile of the respondents with percentage.

Below Fig 2 showed the analysis of the attitude of the respondents by figuring the question, "Should green reporting be implicated in all companies?" When 120 respondents were queried if green reporting has to be implicated in all the companies, $88.34 \%$ of the people agreed and strongly agreed that it has to be implicated 
in all the companies and $8.33 \%$ of them were neutral about it and also, $3.33 \%$ of the people disagreed to it.

Through this response we can conclude that, even though a smaller number of people disagree about green reporting being implicated in all the companies, majority of the people think that green reporting has to be implicated in all of the companies as it helps the companies to keep track of what it is taking from the environment and what it is giving back in return.

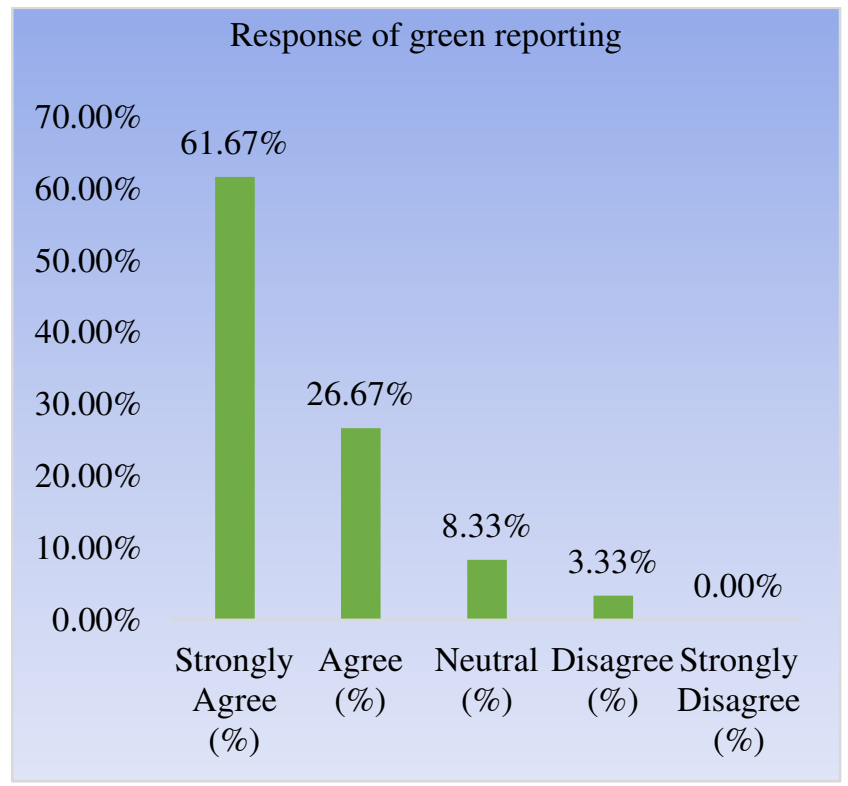

Fig 2: Response of green reporting is implicated in all companies.

From the below Fig 3 showed the analysis of the attitude of the respondents by figuring the question, "Should much more awareness be created about green reporting?" Here, the respondents were inquired if more awareness has to be created for green reporting and the response was as follows; Here, in the second graph, we can see that $3.33 \%$ of the respondents do not agree about more awareness being created about green reporting where as majority of the respondents which constitute $92.5 \%$ of the people, strongly agreed and agreed to the fact that there has to be awareness created everywhere among people and companies regarding green reporting, and $4.17 \%$ of them were neutral, since not many of the people know what it actually means and how it actually helps the company as well as the environment and how benefiting it actually is.

\section{Response of much more awareness}

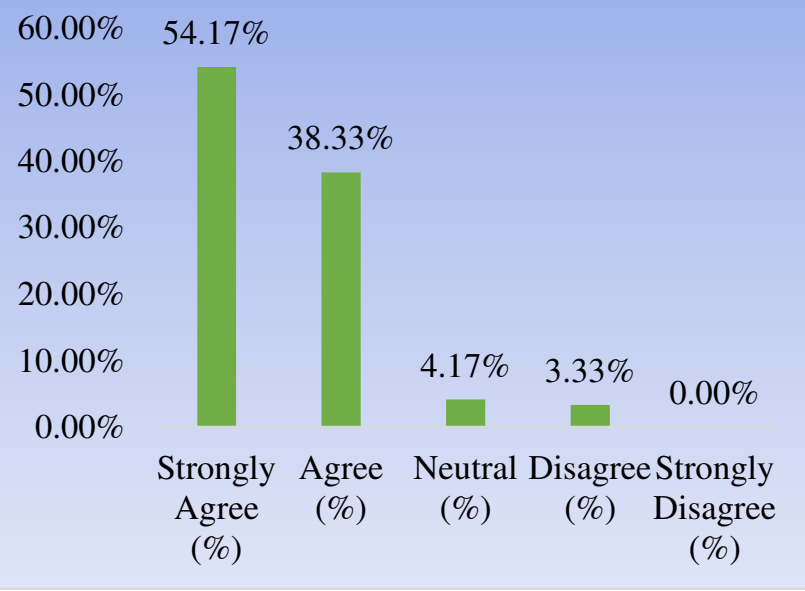

Fig 3: Response of much more awareness is created about green reporting.

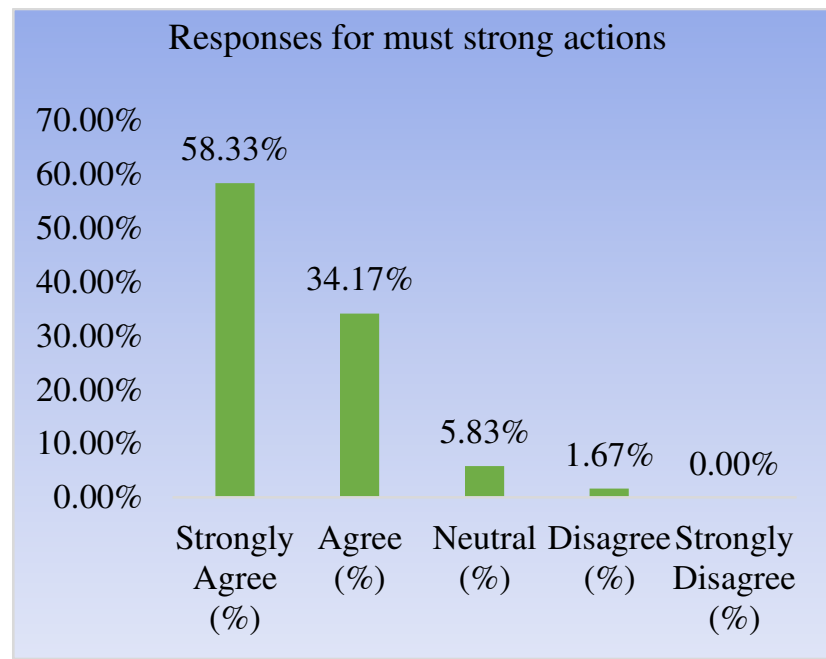

Fig 4: Responses for must strong actions have to be taken by the government if green reporting is not followed.

Fig 4 showed the analysis of the attitude of the respondents by figuring the question, "Must strong actions have to be taken by the government if green reporting is not followed?" Further, when a statement was put up for the respondents if strict actions must be taken by the government if green reporting is not followed, $1.67 \%$ of them disagreed with it. Moreover, the majority of them, $58.33 \%$ of the respondents strongly agreed and $34.17 \%$ of the respondents agreed with the statement that obviously, strict actions must be taken by the government if green reporting is not followed. And also $5.83 \%$ of them were neutral about it. 
Table 2: Data Summary of the study.

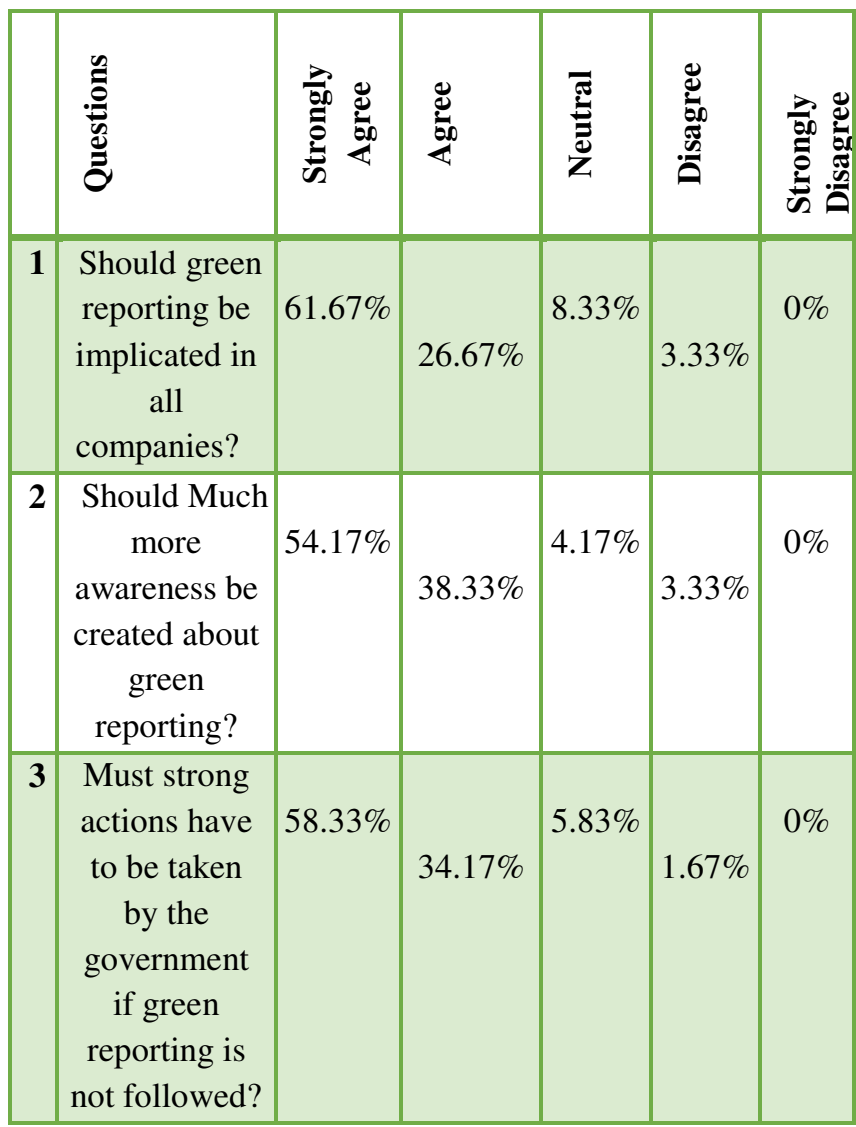

Source: Authors' Calculation

Now, Table 2 figures out the data summary from where we clearly understand that the maximum of the 120 respondents realized the need of green reporting in the present era. Therefore, we can say that for the forthcoming era, the practices of green reporting would be a policy dialog to attain the environmental sustainability. Though very lower number of respondents was in disagree scoring, it cannot hamper the overall decision of the participants as it included maximal percentage of "agree and strongly agree".

The most of the respondents regarding "Question 1", "Question 2" and "Question 3" provided strong positive attitude towards green reporting implication as a tool of environmental sustainability and completed our study assured.

\section{CONCLUSION:}

According to this study, we can conclude that green reporting supports the company as well as the environmental sustainability in various ways and also, this study discovers what the meaning of green accounting or green reporting is and what its features are and how it works. Major changes can be fetched for the betterment of the environment with sustainability, when green reporting would be applied in all sections of the company. Through the literature review, this studies also efforts to notice how much significant the green reporting implementation is for companies for better utilization of resources and also for ensuring environmental sustainability. It is the demand of the period that corporate prepares a firm's green policy, execute steps for contamination control, conform to the associated rules and guidelines, and remark satisfactory details of environmental aspects in the annual statements. For the sustainable development of a country, a well organized environmental policy together with suitable follow up and appropriate accounting practice is obligatory. Because of the depletion of natural resources, green reporting aids us to retain a way of it and how it can be used and what can be completed for determined utilization of it. As the data collected from the primary source, we can derive a conclusion that most of the people are in the favor of green reporting and its implication in the company and also about government being firm about its directions and protocols towards green reporting.

\section{Drawbacks of the study and scope for further} study: The sample designated for the study suffers from many restraints. Sample was carefully chosen at micro level. The selection of respondents was constructed on their willingness to partake. Present study chooses only three factors for considering green reporting; however, forth coming researchers can contemplate the other dimensions. They can determine more fitting sampling techniques.

In this paper, the data are collected only from the primary sources. This study did not consider the secondary data in the methodology segment of the study. Secondary data can be composed from various sources, and a lot of analysis can be done with the help of the collected secondary data. Numerous companies' green reports can be composed and a comparative variable can be executed so that the participants could evaluate the outcomes before taking their investment decisions. 


\section{ACKNOWLEDGEMENT:}

Thanks to all those persons, who have assisted us, providing us co-operation. This paper is under selffunded.

\section{CONFLICTS OF INTEREST:}

Authors declare no conflicts of interest to publish it.

\section{REFERECES:}

1. Abdel-Rahim, M., H. Y. \& Abdel-Rahim, Y. M. (2010). Green accounting- a proposition for $E A / E R$ conceptual implementation methodology. J. of Sustainability and Green business, 5, 27-33.

https://www.aabri.com/manuscripts/10449.pdf

2. Agarwal, D. V. \& Kalpaja L. (2018). A study on the importance of green accounting. International Journal of Advance Research, Ideas and Innovations in Technology, 4, 206210.

https://www.ijariit.com/manuscripts/v4i5/V4I51234.pdf

3. Boje, D. M. (1999). TD Green Environmental Accounting Links to Critical Postmodern Thinking. https://web.nmsu.edu/ dboje/TDgreenlinks.html

4. Chauhan, M. (2005). Concept of Environmental Accounting and Practice in India. The Chartered Accountant, p720-726.

5. Commission, T. E. (2011). Green Accounting as a path to a sustainable future.

6. Contributors, W. (2020). Green accounting. Wikipedia, The Free Encyclopedia. https://en.wikipedia.org/wiki/Green_accounting

7. Gazi MAI. (2020). E-marketing practice in Bangladesh: an empirical study on trend of use and expansion in business, Can. J. Bus. Inf. Stud., 2(1), 12-23.

https://doi.org/10.34104/cjbis.020.012023
8. Government, J. (2004). Environmental Reporting Guidelines. Ministry of the Environment. https://www.env.go.jp/policy/jhiroba/PRG/pdfs/e_guide.pdf

9. Government, J. (2005). Environmental Accounting Guidelines. Ministry of the Environment. https://www.env.go.jp/en/policy/ssee/eag05.pdf

10. Harazin P. \& Horvath, G. (2011). The relation between environmental accounting and the pillars of sustainability. World Academy of Science, Engineering, and Technology. 59, 1881-1886.

http://citeseerx.ist.psu.edu/viewdoc/download?d oi=10.1.1.222.1111\&rep=rep1\&type=pdf

11. Hecht, J. (1997). Environmental Accounting and IUCN. IUCN. Washington, DC: IUCN US. https://portals.iucn.org/library/node/7219

12. Kolk, A. (2000). Green Reporting. Harvard Business Review. https://hbr.org/2000/01/green-reporting

13. Lehman, G. (2011). The Management of Sustainability: The Art of Interpretation. JAMA, 9(1), 23-27.

14. Malik P. \& Mittal, A. (2015). A Study of Green Accounting Pratices in India. International Journal of Commerce, Business and Management, 4(6), 779-787. https://www.academia.edu/40261720/A_Study_ of_Green_Accounting_Practices_in_India

15. Otte, G. (2008). GHG Emissions Accounting. Accounting, Organizations and society, 27, 687-708.

http://www.uww.edu/supplychain/761Green/Ac count.pdf

16. Serafy, S. E. (1997). Green Accounting and Economic Policy. Ecological Economics, 21, 217-229.

https://doi.org/10.1016/S0921-8009(96)0010 7-3

Citation: Rahman MM., and Rahman MS. (2020). Green reporting as a tool of environmental sustainability: some observations in the context of Bangladesh, Int. J. Manag. Account. 2(2), 31-37. https://doi.org/10.34104/ijma.020.031037 (9) 